\title{
KEABSAHAN PEMINDAHTANGANAN BARANG MILIK DAERAH BERUPA TANAH MELALUI JUAL BELI
}

\author{
Abdillah Muhammad Zuhdi \\ Magister Ilmu Hukum, Fakultas Hukum, Universitas Airlangga \\ e-mail: abdillah_mz@hotmail.com \\ Aghnia Risqa Hudiyahrahma \\ Magister Kenotariatan, Fakultas Hukum, Universitas Airlangga \\ e-mail:aghaghnia@gmail.com
}

\begin{abstract}
ABSTRAK
Pemerintah Daerah mempunyai aset berupa tanah sebagai barang milik daerah. Status barang milik daerah adalah Hak Pakai atau Hak Pengelolaan. Berdasarkan Peraturan Pemerintah No. 27 Tahun 2014 juncto Peraturan Menteri Dalam Negeri No. 19 Tahun 2016, barang milik daerah berupa tanah dipindahtangankan oleh Pemerintah Daerah kepada pihak ketiga melalui jual beli. Pemindahtanganan barang milik daerah berupa tanah melalui jual belii tidak sah disebabkan Pemerintah Daerah tidak mempunyai kewenangan untuk memindahtangankan barang milik daerah berupa tanah melalui jual beli kepada pihak ketiga. Barang milik daerah berupa tanah yang berstatus Hak Pakai atau Hak Pengelolaan tidak dapat dipindahtangankan oleh Pemerintah Daerah kepada pihak ketiga melalui jual beli. Upaya hukum yang dapat ditempuh oleh pihak ketiga untuk mendapatkan barang milik daerah berupa tanah berstatus Hak Pakai atau Hak Pengelolaan melalui pelepasan hak yaitu Pemerintah Daerah melepaskan barang milik daerah berupa tanah berstatus Hak Pakai atau Hak Pengelolaan untuk kepentingan pihak ketiga dengan pemberian ganti kerugian oleh pihak ketiga kepada Pemerintah Daerah. Pelepasan hak barang milik daerah berupa tanah berstatus Hak Pakai atau Hak Pengelolaan oleh Pemerintah Daerah dilakukan dengan persetujuan Dewan Perwakilan Rakyat Daerah.
\end{abstract}

Kata Kunci: Tanah Aset Daerah; Hak Pakai; Hak Pengelolaan; pelepasan hak

\section{ABSTRACTS}

The local government has land assets as the regional property. The status of goods belonging to the region is the Right to Use or the Management Rights. Based on Government Regulation No. 27 of 2014 juncto the regulation of Minister of Home Affairs No. 19 of 2016, regional property in the form of land is transferred by the Regional Government to third parties through buying and selling. Transfer of land regional property in the form of land through illegal sale due to the Regional Government not having the authority to transfer regional property in the form of land through buying and selling to third parties. Regional property in the form of land with the right of use or management rights cannot be transferred by the Regional Government to third parties through buying and selling. Legal remedies that can be taken by third parties to obtain regional property in the form of Land Use Rights or Management Rights through the release of rights, namely the Regional Government releases the regional property in the form of Land Use Rights or Management Rights for the benefit of third parties with compensation by third parties to the Regional Government. The release of regional property rights in the form of land with the right of use or management rights by the Regional Government is carried out with the approval of the Regional People's Representative Assembly.

Keywords: The Regional Land Asset; Rights to Use; Management Rights; release of rights 


\section{PENDAHULUAN}

Pemerintah Daerah diatur dalam Pasal 18 Undang-Undang Dasar Negara Republik Indonesia Tahun 1945, yaitu Negara Kesatuan Republik Indonesia dibagi atas daerah-daerah provinsi dan daerah provinsi dibagi atas kabupaten dan kota, yang tiap-tiap provinsi, kabupaten dan kota mempunyai pemerintahann daerah, yang diatur dengan UndangUndang. Pemerintah Daerah Provinsi, Pemerintaah Daerah Kabupaten, dan Pemerintah Daerah Kota memiliki Dewan Perwakilan Rakyat Daerah yang anggota-anggotanya dipilih melalui Pemilihan Umum. Gubernur, Bupati, dan Walikota masingmasing sebagai kepala pemerintah daerah provinsi, kabupaten, dan kota dipilih secara demokratis.

Saat ini, Pemerintah Daerah diatur dalam Undang-Undang No. 23 Tahun 2014 tentang Pemerintahan Daerah. Undang-Undang No. 23 Tahun 2014 mencabutt dan menyatakan tidak berlaku Undang-Undang No. 32 Tahun 2004 tentang Pemerintahan Daerah. Undang-Undang No. 23 Tahun 2014 diubah oleh Peraturan Pemerintah Pengganti Undang-Undang No. 2 Tahun 2014 tentang Perubahan Atas Undang-Undang Nomor 23 Tahun 2014 tentang Pemerintahan Daerah, dan diubah lagi oleh Undang-Undang No. 9 Tahun 2015 tentang Perubahan Kedua Atas Undang-Undang Nomor 23 Tahun 2014 tentang Pemerintahan Daerah.

Pembagian daerah dalam Negara Kesatuan Republik Indonesia ditetapkan dalam Pasal 2 Undang-Undang No. 23 Tahun 2014, yaitu Negara Kesatuan Republik Indonesia dibagi atas daerah provinsi dan daerah provinsi dibagi atas daerah kabupaten dan kota. Daerah kabupaten dan kota dibagi atas kecamatan dan kecamatan dibagi atas kelurahan dan/atau desa.

Pemerintah Daerah dibagi 2 (dua), yaitu Pemerintah Provinsi dan Pemerintah Kabupaten/ Kota. Pemerintah Provinsi dan Pemerintah Kabupaten/Kota memiliki barang milik daerah sebagai aset (kekayaan) berupa tanah. Barang milik daerah berupa tanah dimiliki oleh Pemerintah Daerah untuk melaksanakan tugas pokok dan fungsinya.

Barang milik daerah diatur dalam UndangUndang No. 1 Tahun 2004 tentang Perbendaharaan Negara. Barang Milik Daerah adalah semua barang yang dibeli atau diperoleh atas beban Anggaran Pendapatan dan Belanja Daerah (APBD) atau berasal dari perolehan lainnya yang sah (Pasal 1 angka 11 Undang-Undang No. 1 Tahun 2004 juncto Pasal 1 angka 1 Peraturan Pemerintah No. 27 Tahun 2014 tentang Pengelolaan Barang Milik Negara/Daerah).

Ruang lingkup Barang Milik Daerah ditetapkan dalam Pasal 2 Peraturan Pemerintah No. 27 Tahun 2014 juncto Pasal 2 Peraturan Menteri Dalam Negeri No. 19 Tahun 2016 tentang Pedoman Pengelolaan Barang Milik Daerah, yaitu barang yang dibeli atau diperoleh atas beban Anggaran Pendapatan dan Belanja Daerah, atau barang yang berasal dari perolehan lainnya yang sah meliputi barang yang diperoleh dari hibah/sumbangan atau yang sejenis, barang yang diperoleh sebagai pelaksanaan dari perjanjian/kontrak, barang yang diperoleh sesuai dengan ketentuan peraturan perundang-undangan, atau barang yang diperoleh berdasarkan putusan pengadilan yang telah berkekuatan hukum tetap.

Barang milik daerah ada yang berbentuk benda bergerak dan ada yang berbentuk benda tidak bergerak. Barang milik daerah yang berbentuk benda tidak bergerak berupa tanah dalam status hak tertentu dan/atau bangunan. Barang milik daerah berupa tanah berstatus Hak Pakai atau Hak Pengelolaan. Berdasarkan ketentuan Pasal 43 ayat (1) Peraturan Pemerintah No. 27 Tahun 2014, barang milik daerah berupa tanah harus disertipikatkan oleh Pemerintah Daerah sehingga diterbitkan Sertipikat Hak Pakai atau Sertipikat Hak Pengelolaaan atas nama Pemerintah Daerah oleh Kantor Pertanahan Kabupaten/Kota.

Barang milik daerah berupa tanah ada yang dipergunakan untuk kepentingan pelaksanaan tugas Pemerintah Daerah sendiri, atau ada yang dipergunakan oleh pihak ketiga yang berbentuk perseorangan atau badan hukum atas persetujuan dari Pemerintah Daerah. Barang milik daerah dapat dipindahtangankan kepada pihak lain berdasarkan ketentuan Pasal 54 Peraturan Pemerintah No. 27 Tahun 2014 juncto Pasal 329 Peraturan Menteri Dalam Negeri No. 19 Tahun 2016, yaitu pemindahtanganan barang milik daerah dilakukan dengan cara: a. Penjualan; b. Tukar menukar; c. Hibah; atau d. Penyertaan Modal Pemerintah Daerah.

Alasan barang milik daerah dipindahtangankan oleh Pemerintah Daerah kepada pihak lain adalah barang milik daerah tersebut tidak lagi diperlukan 
bagi penyelenggaraan tugas Pemerintahan Daerah. Bentuk pemindahtanganan Barang Milik Daerah adalah penjualan, tukar menukar, hibah, atau penyertaan modal Pemerintah Pusat/Pemerintah Daerah. ${ }^{1}$

Salah satu bentuk pemindahtanganan barang milik daerah adalah penjualan atau jual beli. Berdasarkan ketentuan Pasal 54 Peraturan Pemerintah No. 27 Tahun 2014 juncto Pasal 329 Peraturan Menteri Dalam Negeri No. 19 Tahun 2016, barang milik daerah berupa tanah dapat dipindahtangankan oleh Pemerintah Daerah kepada pihak lain melalui jual beli. Dengan dilakukan jual beli barang milik daerah berupa tanah oleh Pemerintah Daerah, maka barang milik daerah berupa tanah berpindah kepada pihak lain.

\section{PERUMUSAN MASALAH}

Keabsahan jual beli barang milik daerah berupa tanah oleh Pemerintah Daerah kepada pihak ketiga.

\section{PEMBAHASAN}

\section{Status Barang Milik Daerah Berupa Tanah}

Dalam Pasal 16 ayat (1) Undang-Undang No. 5 Tahun 1960 tentang Peraturan Dasar Pokokpokok Agraria, atau lebih dikenal dengan sebutan Undang-Undang Pokok Agraria (UUPA) ditetapkan macam-macam hak atas tanah yaitu Hak Milik, Hak Guna Usaha, Hak Guna Bangunan, Hak Pakai, Hak Sewa Untuk Bangunan, Hak Membuka Tanah. Hak Memungut Hasil Hutan, hak atas tanah yang akan ditetapkan dengan Undang-Undang. Dalam Pasal 53 ayat (1) Undang-Undang No. 5 Tahun 1960 (UUPA), ditetapkan macam-macam hak atas tanah yang bersifat sementara yaitu Hak Gadai, Hak Usaha Bagi Hasil, Hak Menumpang, dan Hak Sewa Tanah Pertanian.

Barang milik daerah berupa tanah berstatuss Hak Pakai atau Hak Pengelolaan. Menurut Pasal 41 ayat (1) Undang-Undang No. 5 Tahun 1960 (UUPA), yang dimaksudd Hak Pakai adalah hak untuk menggunakan dan atau memungut hasill dari tanah yaang dikuasai langsung oleh negara atau tanah milik orang lain, yang memberi wewenang dann kewajiban yang ditentukan dalam keputusan pemberiannya oleh pejabat yaang

\footnotetext{
${ }^{1}$ Urip Santoso. (Mei 2019). "Ruislag Tanah Aset Pemerintah Daerah dan Tanah Perseroan Terbatas". Makalah. Surabaya: Fakultas Hukum Universitas Airlangga, h. 10.
}

berwenang memberikannya atau dengan perjanjian dengan pemilik tanahnya, yang bukan perjanjian sewa menyewa atau perjanjian pengolahaan tanah, segala sesuatu asal tidak bertentangan dengan jiwa dan ketentuan-ketentuan Undang-Undang ini”.

Peraturan perundang-undangan yang menetapkaan bahwa Pemerintah Daerah dapat menguasai tanah Hak Pakai, adalah:

a. Pasal 42 Undang-Undang No. 5 Tahun 1960 (UUPA);

b. Pasal 1 Peraturan Menteri Agraria No. 9 Tahun 1965 tentang Pelaksanaan Konversi Hak Penguasaan Atas Tanah Negara dan Kebijaksanaan Selanjutnya;

c. Pasal 1 huruf a Peraturan Menteri Agraria No. 1 Tahun 1966 tentang Pendaftaran Hak Pakai dan Hak Pengelolaan;

d. Pasal 39 Peraturan Pemerintah No. 40 Tahun 1996 tentang Hak Guna Usaha, Hak Guna Bangunan, dan Hak Pakai Atas Tanah;

e. Pasal 49 Peraturan Menteri Negara Agraria/ Kepala Badan Pertanahan Nasional No. 9 Tahun 1999 tentang Tata Cara Pemberian dan Pembatalan Hak Atas Tanah Negara dan Hak Pengelolaan.

Berdasarkan sifatnya, Hak Pakai atas tanah dibagi menjadii 2 (dua) macam, yaitu:

a. Hak Pakai yang bersifat privat

Hak Pakai yang bersifat privat, adalah Hak Pakai yang dikuasai oleh warga negara Indonesia, orang asing yang berkedudukan di Indonesia, Perseroan Terbatas, atau perusahaan asing yang mempunyai perwakilan di Indonesia.

b. Hak Pakai yang bersifat publik

Hak Pakai yang bersifat publik, adalah Hak Pakai yang dikuasai oleh Lembaga Negara, Kementerian, Lembaga Pemerintah Non Kementerian, Pemerintah Provinsi, Pemerintah Kabupaten/Kota, Badan Otorita, Perwakilan Negara Asing, Perwakilan Badan Internasional, badan keagamaan, dan badan sosial.

A.P. Parlindungan menyatakan bahwa Hak Pakai yang dipunyai oleh badan hukum publik disebut Hak Pakai publik ada right to use, yaitu menggunakannya untuk waktu yang tidak terbatas selama pelaksanaan tugas, namun tidak ada right of dispossal, yaitu tidak dapat dialihkan dalam bentuk apapun kepada pihak ketiga dan juga tidak dapat dijadikan objek Hak 
Tanggungan. ${ }^{2}$ Barang miliik daerah berupa tanah berstatus Hak Pakai adalah Hak Pakai yang bersifat publik, yaitu tanah Hak Pakainya ada rigt to use, yaitu Pemerintah Daerah mempunyai hak untuk mempergunakan tanah Hak Pakai untuk keperluan pelaksanaan tugasnya, tetapi tidak ada right of dispossal, yaitu Pemerintah Daerah mempunyai hak untuk tidak mempunyai hak untuk mengalihkan tanah Hak Pakainya dalam bentuk apapun kepaada pihak ketiga dan juga tidak mempunyai hak untuk menjadikan tanah Hak Pakainya sebagai objek Hak Tanggungan.

Pemerintah Daerah yang menguasai tanah Hak Pakai yang bersifat publik mempunyai kewenangan untuk mempergunakan tanah Hak Pakainya untuk waktu yang tidak terbatas dan berlaku selama tanah Hak Pakai dipergunakan untuk kepentingan pelaksanaan tugas, tetapi tidak mempunyai kewenangan untuk memindahkan tanah Hak Pakai kepada pihak lain dan menjadikan jaminan utang dengan dibebani Hak Tanggungan.

Selain Hak Pakai, Baraang milik daerah berupa tanah yang dapat dikuasai oleh Pemerintah Daerah berstatus Hak Pengelolaan. Menurut Pasal 2 ayat (3) Undang-Undang No. 20 Tahun 2000 tentang Perubahan Atas Undang-Undang Nomor 21 Tahun 1997 tentang Bea Perolehan Hak Atas Tanah dan Bangunan juncto Pasal 1 Peraturan Pemerintah No. 112 Tahun 2000 tentang Pengenaan Bea Perolehan Hak Atas Tanah dan Bangunan Karena Pemberian Hak Pengelolaan, yang dimaksud Hak Pengelolaan adalah hak menguasai negara yang kewenangan pelaksanaannya sebagian dilimpahkan kepada pemegang haknya untuk merencanakan peruntukan dan penggunaan tanah, menggunakan tanah untuk keperluan pelaksanaan tugasnya, menyerahkan bagian-bagian tanah Hak Pengelolaan kepada pihak ketiga dan/atau bekerja sama dengan pihak ketiga.

Peraturan perundang-undangan yang menetapkan bahwa Pemerintah Daerah dapat menguasai tanah Hak Pengelolaan, adalah:

a. Pasal 5 Peraturan Menteri Agraria No. 9 Tahun 1965 ;

b. Pasal 1 huruf b Peraturan Menteri Agraria No. 1 Tahun 1966;

${ }^{2}$ A.P. Parlindungan, (Maret - April 1991). "Beberapa Konsep Tentang Hak-hak Atas Tanah". Majalah CSIS. Tahun XX No. 2. Jakarta, h. 135. c. Pasal 5 dan Pasal 6 Peraturan Menteri Dalam Negeri No. 5 Tahun 1974 tentang KetentuanKetentuan Mengenai Penyediaan dan Pemberian Tanah Untuk Keperluan Perusahaan;

d. Pasal 2 Peraturan Pemerintah No. 36 Tahun 1997 tentang Pengenaan Bea Perolehan Hak Atas Tanah dan Bangunan Karena Pemberian Hak Pengelolaan;

e. Pasal 67 Peraturan Menteri Negara Agraria/ Kepala Badan Pertanahan Nasional No. 9 Tahun 1999.

Eman Ramelan menyatakan bahwa subjek atau pemegang Hak Pengelolaan adalah sebatas pada badan hukum Pemerintah baik yang bergerak dalam pelayanan publik (pemerintahan) atau yang bergerak dalam bidang bisnis, seperti Badan Usaha Milik Negara/Badan Usaha Milik Daerah, PT Persero, badan hukum swasta tidak mendapatkan peluang untuk berperan serta sebagai subjek atau pemegang Hak Pengelolaan. ${ }^{3}$

Hak Pengelolaan diberikan kepada badan-badan hukum tertentu, yaitu instansi Pemerintah termasuk Pemerintah Daerah, Badan Usaha Milik Negara, Badan Usaha Milik Daerah, PT Persero, Badan Otorita, dan badan-badan hukum Pemerintah lainnya yang ditunjuk oleh Pemerintah. Tidak setiapp badan hukum dapatt mempunyai Hak Pengelolaan. Badan hukum yang dapat mempunyai Hak Pengelolaan adalah badan hukum yang tugas pokok dan fungsinyaa berkaitan dengan pengelolaan tanah. ${ }^{4}$

Pemerintah Daerah sebagai pemegang Hak Pengelolaan mempunyai kewenangan, yaitu:

a. Merencanakan peruntukan dan penggunaan tanah;

b. Mempergunakan tanah untuk keperluan pelaksanaan tugasnya; dan

c. Menyerahkan bagian-bagian tanah Hak Pengelolaan kepada pihak ketiga dan atau bekerja sama dengan pihak ketiga.

${ }^{3}$ Eman Ramelan. (2006). "Hak Pengelolaan Setelah Berlakunya Peraturan Menteri Negara Agraria/Kepala Badan Pertanahan Nasional No. 9 Tahun 1999". Jurnal YURIDIKA. Vol. 15 No. 3. Surabaya: Fakultas Hukum Universitas Airlangga, h. 196.

4 Urip Santoso. (2018). "Penggunaan Tanah Aset Pemerintah Kota Surabaya Oleh Pihak Ketiga Dalam Bentuk Izin Pemakaian Tanah (Perspektif Hukum Pertanahan)". Jurnal Perspektif. Volume 23 Nomor 3 Edisi September. Surabaya: Fakultas Hukum Universitas Wijaya Kusuma, h. 155. 


\section{Keabsahan Jual Beli Barang Milik Daerah Berupa Tanah}

Pasal 54 Peraturan Pemerintah No. 27 Tahun 2014 juncto Pasal 329 Peraturan Menteri Dalam Negeri No. 19 Tahun 2016 menetapkan bahwa barang milik daerah dapat dipindahtangankan kepada pihak lain dengan cara: a. Penjualan; $b$. Tukar menukar; $c$. Hibah; atau d. Penyertaan Modal Pemerintah Daerah.

Berdasarkan ketentuan Pasal 54 Peraturan Pemerintah No. 27 Tahun 2014 juncto Pasal 329 Peraturan Menteri Dalam Negeri No. 19 Tahun 2016, barang milik daerah berupa tanah dapat dipindahtangankan kepada pihak lain dengan cara penjualan atau jual beli. Dengan penjualan atau jual beli, barang milik daerah berupa tanah berpindah dari Pemerintah Daerah sebagai penjual kepada pihak lain sebagai pembeli.

Penjualan atau jual beli tanah tunduk pada Hukum Tanah Nasional sehingga keabsahan dan prosedur penjualan atau jual beli tanah berdasarkan Hukum Tanah Nasional, yang diatur dalam UndangUndang No. 5 Tahun 1960 (UUPA) dan peraturan pelaksanaannya.

Undang-Undang No. 5 Tahun (UUPA) dan Peraturan Pemerintah No. 40 Tahun 1996 tentang Hak Guna Usaha, Hak Guna Bangunan, dan Hak Pakai Atas Tanah menetapkan 2 (dua) bentuk peralihan hak atas tanah, yaitu: ${ }^{5}$

a. Beralih

Arti beralih yaitu berpindahnya hak atas tanah dari pemegang haknya kepada pihak lainn disebabkan oleh suatu peristiwa hukum, yaitu meninggal dunianya pemegang hak atas tanah. Berpindahnya hak atass tanah disini terjadi melalui suatu proses pewarisan.

b. Dialihkan

Arti dialihkan yaitu berpindahnyaa hak atas tanah dari pemegang haknya kepada pihak lain disebabkan oleh suatu perbuatan hukum.

Dengan perbuatan hukum, maka hak atas tanah berpindah dari pemegang haknya kepada pihak lain. Contoh perbuatan hukumm adalah jual beli, tukar menukar, hibah, penyertaan dalam modal perusahaan (inbreng), lelang.

\footnotetext{
${ }^{5}$ Urip Santoso. (2017). Hak Atas Tanah, Hak Pengelolaan, dan Hak Milik Atas Satuan Rumah Susun. Jakarta: Kencana Prenada Media, h. 35.
}

Jual beli tanah merupakan salah satu contoh peralihan hak atas tanah yang berbentuk dialihkan. Jual beli tanah merupakan perbuatan hukum yang dimaksudkan untuk memindahkan hak atas tanah dari pemegang hak atas tanah sebagai penjual kepada pihak lain sebagai pembeli. Akibat hukum dari jual beli tanah adalah hak atas tanah berpindah dari pemegang hak atas tanah sebagai penjual kepada pihak lain sebagai pembeli.

Objek jual beli tanah bukan tanah dalam pengertian fisik, melainkan tanah dalam pengertian hak, yaitu hak atas tanah. Hak atas tanah yang menjadi objek jual beli tanah adalah Hak Milik, Hak Guna Usaha, Hak Guna Bangunan, dan Hak Pakai. Selain hak atass tanah, hak yang dapat menjadi objek jual beli tanah adalah Hak Milik Atas Satuan Rumah Susun.

Boedi Harsono memberikan pengertian jual beli tanah adalah perbuatan hukum, yang berupa penyerahan Hak Milik (penyerahan tanah untuk selama-lamanya) oleh penjual kepada pembeli, yang pada saat itu juga pembeli menyerahkan harganya kepada penjual. Jual beli yang mengakibatkan beralihnya Hak Milik atas tanah dari penjual kepada pembeli itu termasuk dalam Hukum Agraria atau Hukum Tanah. ${ }^{6}$ Menurut Urip Santoso, jual beli tanah adalah perbuatan hukum berupa penyerahan hak atas tanah untuk selama-lamanya oleh pemilik tanah atau pemegang hak atas tanah sebagai penjual kepada pihak lain sebagai pembeli, dan secara bersamaan pihak pembeli menyerahkan sejumlah uang sebagai harga, yang besarnya sesuai dengan kesepakatan kedua belah pihak. ${ }^{?}$

Menurut Maria S.W, Sumardjono, sifat jual beli tanah menurut Hukum Adat, adalah: ${ }^{8}$

a. Tunai

Tunai artinya penyerahan hak atas tanah oleh pemilik tanah (penjual) dilakukan bersamaan dengan pembayaran harganya oleh pihak lain (pembeli).

\footnotetext{
${ }^{6}$ Boedi Harsono. (1971). Undang-Undang Pokok Agraria Isi dan Pelaksanaannya. Jakarta: Djambatan, h. 135.

${ }^{7}$ Urip Santoso. (20115). Perolehan Hak Atas Tanah. Jakarta: Kencana Prenada Media, h. 133.

${ }^{8}$ Maria S.W. Sumardjono. (1993). "Aspek Teoritis Peralihan Hak Atas Tanah Menurut UUPA”. Majalah Mimbar Hukum. No. 18/X/1993. Yogyakarta: Fakultas Hukum Universitas Gadjah Mada, h. 11.
} 
Dengan perbuatan hukum jual beli tersebut, maka seketika itu juga terjadi peralihan hak atas tanah. Harga yang dibayarkan pada saat penyerahan hak tidak harus lunas atau penuh dan hal ini tidak mengurangi sifat tunai tadi. Kalau ada selisih/ sisa dari harga, maka hal itu dianggap sebagai utang pembeli kepada penjual.

b. Riil

Riil artinya kehendak atau niat yang diucapkan harus diikuti dengan perbuatan yang nyata yang menunjukkan tujuan jual beli tersebut, misalnya dengan diterimanya uang oleh penjual dan dibuatnya perjanjian di hadapan kepala desa.

c. Terang

Terang artinya untuk perbuatan hukum tersebut haruslah dilakukan di hadapan kepala desa sebagai tanda bahwa perbuatan hukum itu tidak melanggar ketentuan hukum yang berlaku.

Ada 2 (dua) syarat sah dalam pendaftaran pemindahan hak atas tanah melalui jual beli, yaitu: ${ }^{9}$

a. Syarat materiil

Syarat materiil, yaitu pemegang hak atas tanah sebagai penjual tanah berhak dan berwenang untuk menjual hak atas tanahnya, dan pembeli harus memenuhi syarat sebagai subjek hak atas tanah yang menjadi objek jual beli tanah.

Pembeli tanah harus memenuhi syarat sebagai subjek hak atas tanah yang menjadi objek jual beli tanah. Kalau objek jual beli tanah berstatus Hak Milik, maka pembeli harus memenuhi syarat sebagai subjek Hak Milik.

Hak atas tanah yang menjadi objek jual beli tidak sedang dalam sengketa, tidak sedang dalam jaminan utang, dan tidak sedang dalam sitaan pihak lain.

b. Syarat formal

Dalam rangka pendaftaran pemindahan hak atas tanah, maka jual beli tanah harus dibuktikan dengan akta yang dibuat oleh Pejabat Pembuat Akta Tanah (PPAT) yang berwenang, sebagaimana ditetapkan dalam Pasal 37 ayat (1) Peraturan Pemerintah No. 24 Tahun 1997 tentang Pendaftaran Tanah menyatakan bahwa: "Peralihan hak atas tanah dan hak milik atas satuan rumah susun melalui jual beli, tukar

\footnotetext{
${ }^{9}$ Urip Santoso. (2019). Pendaftaran dan Peralihan Hak Atas Tanah. Cet. VI. Jakarta: Kencana Prenada Media, h. 363367.
}

menukar, hibah, pemasukan dalam perusahaan dan perbuatan hukum pemindahan hak lainnya, kecuali pemindahan hak melalui lelang hanya dapat didaftarkann jika dibuktikan dengan akta yang dibuat oleh Pejabat Pembuat Akta Tanah (PPAT) yang berwenang menurut ketentuan peraturan perundang-undangann yang berlaku". Jual beli tanah dapat didaftarkan ke Kantor Pertanahan Kabupaten/Kota jika jual beli tanah dibuktikan dengan akta yang dibuat oleh dan dihadapan Pejabat Pembuat Akta Tanah (PPAT) yang berwenang. Maksud pendaftaran jual beli tanah ke Kantor Pertanahan Kabupaten/Kota adalah untuk mengubah nama pemegang hak atas tanah dalam sertipikat hak atas tanah dari atas nama penjual menjadi atas nama pembeli. Dengan pendaftaran jual beli tanah ke Kantor Pertanahan Kabupaten/Kotaa terwujud jaminan kepastian hukum, perlindungan hukum, dan tertib administrasi pertanahan.

Barang milik daerah berupa tanah berstatus Hak Pakai atau Hak Pengelolaan. Menurut Pasal 54 ayat (1) Peraturan Pemerintah No. 40 Tahun 1996, Hak Pakai yang diberikan atas tanah negara untuk jangka waktu tertentu dan Hak Pakai atas tanah Hak Pengelolaan dapat beralih dan dialihkan kepada pihak lain. Berdasarkan ketentuan Pasal 54 ayat (1) Peraturan Pemerintah No. 40 Tahun 1996, Hak Pakai atas tanah negara yang tidak berjangka waktu tertentu, yang berlaku selama tanahnya dipergunakan untuk keperluan pelaksanaan tugasnya tidak dapat beralih dan dialihkan kepada pihak lain.

Dalam Penjelasan Pasal 45 ayat (1) Peraturan Pemerintah No. 40 Tahun 1996 dinyatakan bahwa Hak Pakai yang diberikan untuk jangka waktu yang tidak ditentukan selama tanahnya dipergunakan untuk keperluan tertentu tidak dapat dialihkan kepada pihak lain, akan tetapi dapat dilepaskan oleh pemegang haknya sehingga menjadi tanah negara untuk kemudian dimohon dengan hak baru oleh pihak lain tersebut. Berdasarkan Penjelasan Pasal 45 ayat (1) Peraturan Pemerintah No. 40 Tahun 1996, Hak Pakai yang diberikan kepada Pemerintah Daerah tidak berjangka waktu tertentu, berlaku selama tanahnya dipergunakan untuk keperluan pelaksanaan tugasnya tidak dapat dialihkan kepada pihak lain, akan tetapi dapat dilepaskan oleh Pemerintah Daerah sebagai pemegang haknya untuk kepentingan pihak lain dengan atau tanpa pemberian ganti kerugian. 
Barang milik daerah berupa tanah berstatus Hak Pakai bersifat right to use, yaitu Pemerintah Daerah hanya berhak mempergunakan tanah Hak Pakainya untuk keperluan pelaksanaan tugasnya, yang dipergunakan tanpa batas jangka waktu. Barang milik daerah berupa tanah berstatus Hak Pakai tidak bersifat right of dispossal, yaitu Pemerintah Daerah tidak berhak memindahtangankan atau mengalihkan tanah Hak Pakainya kepada pihak lain atau menjadikan tanah Hak Pakainya sebagai jaminan utang dengan dibebani Hak Tanggungan.

Berdasarkan syarat sahnya pendaftaran jual beli tanah, barang milik daerah berupa tanah berstatus Hak Pakai tidak dapat diperjualbelikan kepada pihak lain disebabkan tidak memenuhi syarat materiil, yaitu Pemerintah Daerah sebagai pemegang Hak Pakai tidak berwenang memperjualbelikan tanah Hak Pakainya kepada pihak lain. Oleh karena syarat materiil tidak dapat dipenuhi oleh Pemerintah Daerah, maka syarat formalnya tidak dapat dipenuhi oleh Pemerintah Daerah, yaitu jual beli tanah Hak Pakai yang dikuasai oleh Pemerintah Daerah tidak dapat dibuktikan dengan akta Pejabat Pembuat Akta Tanah (PPAT). Dengan demikian, jual beli tanah Hak Pakai yang dikuasai oleh Pemerintah Daerah tidak dapat didaftarkan ke Kantor Pertanahan Kabupaten/ Kota.

Barang milik daerah berupa tanah berstatus Hak Pengelolaan, Pemerintah Daerah sebagai pemegang Hak Pengelolaan mempunyai wewenang, yaitu merencanakan peruntukan dan penggunaan tanah, mempergunakan tanah untuk keperluan pelaksanaan tugasnya, dan menyerahkan bagian-bagian tanah Hak Pengelolaan kepada pihak ketiga dan atau bekerja sama dengan pihak ketiga. Berdasarkan wewenang dalam Hak Pengelolaan, Pemerintah Daerah sebagai pemegang Hak Pengelolaan tidak mempunyai wewenang memindahtangankan tanah Hak Pengelolaannya kepada pihak lain, melainkan Pemerintah Daerah mempunyai wewenang menyerahkan bagian-bagian tanah Hak Pengelolaan kepada pihak ketiga dan atau bekerja sama dengan pihak ketiga.

Barang milik daerah berupa tanah berstatus Hak Pengelolaan bersifat right to use, yaitu Pemerintah Daerah hanya berhak mempergunakan tanah Hak Pengelolaan untuk keperluan pelaksanaan tugasnya, yang dipergunakan tanpa batas jangka waktu. Barang milik daerah berupa tanah berstatus Hak Pengelolaan tidak bersifat right of dispossal, yaitu Pemerintah Daerah tidak berhak memindahtangankan atau mengalihkan tanah Hak Pengelolaannya kepada pihak lain atau menjadikan tanah Hak Pengelolaannya sebagai jaminan utang dengan dibebani Hak Tanggungan.

Berdasarkan syarat sahnya pendaftaran jual beli tanah, barang milik daerah berupa tanah berstatus Hak Pengelolaan tidak dapatt diperjualbelikan kepada pihak lain disebabkan tidak memenuhi syarat materiil, yaitu Pemerintah Daerah sebagai pemegang Hak Pengelolaan tidak berwenang memperjualbelikan tanah Hak Pengelolaannya kepada pihak lain. Oleh karena syarat materiil tidak dapat dipenuhi oleh Pemerintah Daerah, makaa syarat formalnya tidak dapat dipenuhi oleh Pemerintah Daerah, yaitu jual beli tanah Hak Pengelolaan yang dikuasai oleh Pemerintah Daerah tidak dapat dibuktikan dengan akta Pejabat Pembuat Akta Tanah (PPAT). Dengan demikian, jual beli tanah Hak Pengelolaan yang dikuasai oleh Pemerintah Daerah tidak dapat didaftarkan ke Kantor Pertanahan Kabupaten/Kota.

\section{Upaya Hukum Pihak Ketiga Untuk Mendapatkan Barang Milik Daerah Berupa Tanah}

Barang milik daerah berupa tanah berstatus Hak Pakai dan Hak Pengelolaan bersifat right to use dan tidak bersifat right of dispossal, yaitu Pemerintah Daerah sebagai pemegang Hak Pakai dan Hak Pengelolaan hanya berhak mempergunakan tanah Hak Pakai dan Hak Pengelolaannya untuk keperluan pelaksanaan tugasnya, yang dipergunakan tanpa batas jangka waktu. Pemerintah Daerah sebagai pemegang Hak Pakai dan Hak Pengelolaaan tidak berhak memindahtangankan atau mengalihkan tanah sebagai pemegang Hak Pakai dan Hak Pengelolaannya kepada pihak lain atau menjadikan tanah sebagai pemegang Hak Pakai dan Hak Pengelolaannya sebagai jaminan utang dengan dibebani Hak Tanggungan.

Berdasarkan Penjelasan Pasal 45 ayat (1) Peraturan Pemerintah No. 40 Tahun 1996, Hak Pakai yang diberikan kepada Pemerintah Daerah tidak berjangka waktu tertentu, berlaku selama tanahnya dipergunakan untuk keperluan pelaksanaan tugasnya tidak dapat dialihkan kepada pihak lain, akan tetapi dapat dilepaskan oleh Pemerintah Daerah sebagai 
pemegang haknya untuk kepentingan pihak lain dengan atau tanpa pemberian ganti kerugian.

Dalam Pasal 55 ayat (1) huruf c Peraturan Pemerintah No. 40 Tahun 1996 dinyatakan bahwa Hak Pakai hapus karena dilepaskan oleh pemegang haknya sebelum jangka waktuu berakhir. Hak Pakai sebagai suatu hak atas tanah dapat hapus karena dilakukan pelepaskan hak secara sukarela oleh pemegang haknya dengan atau tanpa pemberian ganti kerugian.

Berdasarkan wewenang dalam Hak Pengelolaan, Pemerintah Daerah sebagai pemegang Hak Pengelolaan tidak mempunyai wewenang mmemindahtangankan tanah Hak Pengelolaannya kepada pihak lain, melainkan Pemerintah Daerah mempunyai wewenang menyerahkan bagian-bagian tanah Hak Pengelolaan kepada pihak ketiga dan atau bekerja sama dengan pihak ketiga. Urip Santoso menyatakan bahwa pemegang Hak Pengelolaan berwenang menyerahkan bagian-bagian tanah Hak Pengelolaan kepada pihak ketiga untuk selamalamanya. Penyerahan bagian-bagian tanahh Hak Pengelolaan kepada pihak ketiga untuk selamalamanya tidak ditempuh dengan cara perjanjian penggunaan tanah, melainkan ditempuh dengan cara pelepasan Hak Pengelolaan oleh pemegang haknya. ${ }^{10}$

Oleh karena Pemerintah Daerah sebagai pemilik barang milik daerah berupa tanah berstatus Hak Pakai dan Hak Pengelolaan tidak berwenang memindahtangankan melalui jual beli barang milik daerah berupa tanah berstatus Hak Pakai dan Hak Pengelolaan, maka pihak ketiga yang ingin mendapatkan barang milik daerah berupa tanah berstatus Hak Pakai dan Hak Pengelolaan ditempuh melalui pelepasan hak atas barang milik daerah berupa tanah berstatus Hak Pakai dan Hak Pengelolaan. Pemerintah Daerah sebagai pemilik brang milik daerah berupa tanah berstatuss Hak Pakai dan Hak Pengelolaan melakukan pelepasan hak atas barang milik daerah berupa tanah berstatus Hak Pakai dan Hak Pengelolaan untuk kepentingan pihak ketiga dengan atau tanpa pemberian ganti kerugian.

Abdurrahman memberikan pengertian pelepasan hak adalah perbuatan seseorang pemegang hak untuk melepaskan apa yang menjadi haknya secara

\footnotetext{
${ }^{10}$ Urip Santoso. (2017). Hak Atas Tanah, Hak Pengelolaan, dan Hak Milik Atas Satuan Rumah Susun. Jakarta: Kencana Prenada Media, h. 209.
}

sukarela setelah kepadanya diberikan suatu ganti rugi yang layak. ${ }^{11}$ Irene Eka Sihombing menyatakan bahwa pelepasan hak adalah perbuatan melepaskann hubungan hukm antara pemegang hak atas tanah dengan tanahnya disertai pemberian imbalan yang disepakati bersama atas dasar musyawarah antara pihak yang memerlukan tanah dengan pemilik tanah mengenai besarnya imbalan atas tanah berikut bangunan ataupun benda-benda yang melekat pada tanah. ${ }^{12}$ Pelepasan hak menurut Urip Santoso adalah kegiatan memutuskan hubungan hukum antara pihak yang berhak dengan tanah yang dikuasainyaa dan berakibat hak atas tanah menjadi hapus dan tanahnya kembali menjadi tanah yang dikuasai langsung oleh negara. ${ }^{13}$

Pengertian pelepasan hak dinyatakan dalam Pasal 1 angka 9 Undang-Undang No. 2 Tahun 2012 tentang Pengadaan Tanah Bagi Pembangunan Untuk Kepentingan Umum juncto Pasal 1 angka 9 Peraturan Presiden No. 148 Tahun 2015 tentang Perubahan Keempat Peraturan Presiden Nomor 71 Tahun 2012 tentang Penyelenggaraan Pengadaan Tanah Bagi Pembangunan Untuk Kepentingan Umum, yaitu kegiatan pemutusan hubungan hukum dari pihak yang berhak kepada negara melalui Lembaga Pertanahan (Badan Pertanahan Nasional RI).

Dengan telah dilakukan pelepasan hak oleh pemegang hak atas tanah, maka terputus hubungan hukum antara pemegang hak atas tanah dengan hak atas tanah yang dikuasainya. Dengan telah dilakukan pelepasan hak oleh pemegang hak atas tanah, maka pemegang hak atas tanah tidak lagi memiliki atau menguasai hak atas tanahnya.

Akibat hukum pelepasan hak atas tanah dikemukakan oleh Boedi Harsono, yaitu dengan pelepasaan hak atas tanah tidak berarti bahwa hak atas tanah berpindah dari pemegang hak atas tanah kepada pihak lain yang memberikan ganti kerugian, melainkan hak atas tanah tersebut hapus dan kembali

${ }^{11}$ Abdurrahman. (1996). Masalah-masalah Pencabutan Hak Atas Tanah dan Pengadaan Tanah Bagi Pelaksanaan Pembangunan Untuk Kepentingan Umum. Bandung: Citra Aditya Bakti, h. 26.

12 Irene Eka Sihombing. (2017). Segi-Segi Hukum Tanah Nasional Dalam Pengadaan Tanah Untuk Pembangunan, Jakarta: Penerbit Universitas Trisakti, h. 81.

${ }^{13}$ Urip Santoso. (2013). Hukum Pengadaan Tanah Untuk Kepentingan Umum. Surabaya: Airlangga University Press, h. 104. 
menjadi tanah negaraa atau tanah yang dikuasai langsung oleh negara. Pelepasan hak atas tanah merupakan salah satu faktor penyebab hapusnya hak atas tanah dan bukan pemindahan hak atas tanah. ${ }^{14}$ Urip Santoso menyatakan bahwa dengan pelepasan hak atas tanah oleh pemegang haknya, hak atas tanah tidak berpindah kepada pihak yang memerlukan tanah, melainkan hak atas tanah menjadi hapus dan tanahnya kembali menjadi tanah negara atau tanah yang dikuasai langsung oleh negara. ${ }^{15}$

Pihak ketiga yang ingin mendapatkan barang milik daerah berupa tanah berstatus Hak Pakai dan Hak Pengelolaan ditempuh melalui pelepasan hak atas barang milik daerah berupa tanah berstatus Hak Pakai dan Hak Pengelolaan oleh Pemerintah Daerah. Pemerintah Daerah melakukan pelepasan hak atas barang milik daerah berupa tanah berstatus Hak Pakai dan Hak Pengelolaan untuk kepentingan pihak ketiga.

Pelepasan hak atas barang milik daerah berupa tanah berstatus Hak Pakai atau Hak Pengelolaan oleh Pemerintah Daerah dapat dibuktikan dengan akta notaris atau surat pernyataan pelepasan hak oleh Pemerintah Daerah. Untuk dapat dilakukan pelepasan hak oleh Pemerintah Daerah harus mendapatkan persetujuan secara tertulis terlebih dahulu oleh Dewan Perwakilan Rakyat Daerah setempat. Persetujuan secara tertulis oleh Dewan Perwakilan Rakyat Daerah setempat diperlukan disebabkan Pemerintah Daerah akan kehilangan asetnya berupa barang milik daerah berstatus Hak Pakai atau Hak Pengelolaan.

Dengan pelepasan hak atas barang milik daerah berupaa tanah berstatus Hak Pakai atau Hak Pengelolaan oleh Pemerintah Daerah tidak berakibat tanah Hak Pakai atau Hak Pengelolaan berpindah kepada pihak ketiga, melainkan berakibat tanah Hak Pakai atau Hak Pengelolaan menjadi hapus dan tanahnya kembali menjadi tanah negara atau tanah yang dikuasai langsung oleh negara.

Setelah dilakukan pelepasan hak atas barang milik daerah berupa tanah berstatus Hak Pakai

\footnotetext{
${ }^{14}$ Boedi Harsono. (April 1990). “Aspek Yuridis Penyediaan Tanah”. Majalah Hukum dan Pembangunan. Nomor 2 Tahun XX. Fakultas Hukum Universitas Indonesia, h. 168.

${ }^{15}$ Urip Santoso. (Oktober 2010). "Perolehan Hak Atas Tanah Untuk Kepentingan Perusahaan Swasta”. Jurnal Pro Justitia. Bandung: Fakultas Hukum Universitas Khatolik Parahiyangan, h. 213.
}

atau Hak Pengelolaan oleh Pemerintah Daerah, pihak ketiga mengajukan permohonan pemberian hak atas tanah negara kepada Menteri Agraria dan Tata Ruang/Kepala Badan Pertanahan Nasional RI melalui Kepala Kantor Pertanahan Kabupaten/Kota setempat. Kalau permohonan pemberian hak atas tanah negara dikabulkan, maka diterbitkan Surat Keputusan Pemberian Hak (SKPH) oleh Menteri Agraria dan Tata Ruang/Kepala Badan Pertanahan Nasinal RI atau dilimpahkan kewenangannya kepada Kepala Kantor Wilayah Badan Pertanahan Nasional Provinsi atau Kepala Kantor Pertanahan Kabupaten/ Kota setempat.

Dalam waktu yang telah ditetapkan dalam Surat Keputusan Pemberian Hak (SKPH), pemohon pemberian hak atas tanah negara mendaftarkan Surat Keputusan Pemberian Hak (SKPH) ke Kantor Pertanahan Kabupaten/Kota setempat untuk diterbitkan sertipikat hak atas tanah sebagai surat tanda bukti hak. Sertipikat hak atas tanah diserahkan oleh Kantor Pertanahan Kabupaten/Kota kepada pemohon pemberian hak atas tanah negara.

\section{PENUTUP \\ Kesimpulan}

Pemindahtanganan barang milik daerah berupa tanah berstatus Hak Pakai atau Hak Pengelolaan melalui penjualan atau jual beli yang ditetapkan dalam Pasal 54 Peraturann Pemerintah No. 27 Tahun 2014 juncto Pasal 329 Peraturan Menteri Dalam Negeri No. 19 Tahun 2016 tidak dapat dilakukan disebabkan bertentangan dengan Hukum Tanah Nasional. Barang milik daerah berupa tanah berstatus Hak Pakai atau Hak Pengelolaan bersifat right to use tidak bersifat right of dispossal. Barang milik daerah berupa tanah berstatus Hak Pakai atau Hak Pengelolaan tidak dapat diperjualbelikan disebabkan tidak memenuhi keabsahan jual beli tanah yaitu syarat materiil dan syarat formal.

Upaya hukum yang dapat ditempuh oleh pihak ketiga untuk mendapatkan barang milik daerah berupa tanah berstatus Hak Pakai dan Hak Pengelolaan tidak melalui jual beli, melainkan ditempuh melalui pelepasan hak atas barang milik daerah berupa tanah berstatus Hak Pakai dan Hak Pengelolaan oleh Pemerintah Daerah. Sebelum dilakukan pelepasan hak atas barang milik daerah berupa tanah berstatus Hak Pakai dan Hak Pengelolaan oleh Pemerintah 
Daerah harus ada persetujuan secara tertulis oleh Dewan Perwakilan Rakyat Daerah setempat. Setelah dilakukan pelepasan hak, pihak ketiga mengajukan permohonan pemberian hak atas tanah negara kepada Menteri Agraria dan Tata Ruang/Kepala Badan Pertanahan Nasional RI melalui Kepala Kantor Pertanahan Kabupaten/Kota setempat untuk mendapatkan hak atas tanah baru. Sebagai tanda bukti pemberian hak atas tanah negara diterbitkan sertipikat hak atas tanah oleh Kantor Pertanahan Kabupaten/Kota setempat.

\section{Rekomendasi}

Perlu ditinjau kembali, Peraturan Pemerintah No. 27 Tahun 2014 dan Peraturan Menteri Dalam Negeri No. 19 Tahun 2016, yang di dalamnya mengatur pemindatanganan barang milik daerah berupa tanah melalui penjualan atau jual beli tidak dapat dilaksanakan disebabkan tidak memenuhi keabsahan, baik secara materiil maupun formal dalam jual beli tanah. Barang milik daerah berupa tanah berstatus Hak Pakai dan Hak Pengelolaan perlu disertipikatkan oleh Pemerintah Daerah agar terwujud jaminan kepastian hukum, perlindungan hukum, dan tertib administrasi pertanahan. Dengan diterbitkannya sertipikat Hak Pakai dan sertipikat Hak Pengelolaan, maka Pemerintah Daerah dengan mudah dapat membuktikan bahwa tanah Hak Pakai dan Hak Pengelolaan tersebut adalah tanah asetnya sebagai barang milik daerah.

\section{DAFTAR PUSTAKA}

\section{Peraturan Perundang-Undangan:}

Undang-Undang Dasar Negara Republik Indonesia Tahun 1945.

Undang-Undang Nomor 5 Tahun 1960 tentang Peraturan Dasar Pokok-pokok Agraria.

Undang-Undang Nomor 20 Tahun 2000 tentang Perubahan Atas Undang-Undang Nomor 21 Tahun 1997 tentang Bea Perolehan Hak Atas Tanah dan Bangunan.

Undang-Undang Nomor 1 Tahun 2004 tentang Perbendaharaan Negara.

Undang-Undang Nomor 32 Tahun 2004 tentang Pemerintahan Daerah.

Undang-Undang Nomor 2 Tahun 2012 tentang Pengadaan Tanah Bagi Pembangunan Untuk Kepentingan Umum.
Undang-Undang Nomor 23 Tahun 2014 tentang Pemerintahan Daerah.

Undang-Undang Nomor 9 Tahun 2015 tentang Perubahan Kedua Atas Undang-Undang Nomor 23 Tahun 2014 tentang Pemerintahan Daerah.

Peraturan Pemerintah Nomor 40 Tahun 1996 tentang Hak Guna Usaha, Hak Guna Bangunan, dan Hak Pakai Atas Tanah.

Peraturan Pemerintah Nomor 24 Tahun 1997 tentang Pendaftaran Tanah.

Peraturan Pemerintah Nomor 36 Tahun 1997 tentang Pengenaan Bea Perolehan Hak Atas Tanah dan Bangunan Karena Pemberian Hak Pengelolaan.

Peraturan Pemerintah Nomor 112 Tahun 2000 tentang Pengenaan Bea Perolehan Hak Atas Tanah dan Bangunan Karena Pemberian Hak Pengelolaan. Peraturan Pemerintah Nomor 27 Tahun 2014 tentang Pengelolaan Barang Milik Negara/Daerah.

Peraturan Presiden Nomor 148 Tahun 2015 tentang Perubahan Keempat Peraturan Presiden Nomor 71 Tahun 2012 tentang Penyelenggaraan Pengadaan Tanah Bagi Pembangunan Untuk Kepentingan Umum.

Peraturan Menteri Agraria Nomor 9 Tahun 1965 tentang Pelaksanaan Konversi Hak Penguasaan Atas Tanah Negara dan Kebijaksanaan Selanjutnya.

Peraturan Menteri Agraria Nomor 1 Tahun 1966 tentang Pendaftaran Hak Pakai dan Hak Pengelolaan.

Peraturan Menteri Dalam Negeri Nomor 5 Tahun 1974 tentang Ketentuan-ketentuan Mengenai Penyediaan dan Pemberian Tanah Untuk Keperluan Perusahaan.

Peraturan Menteri Negara Agraria/Kepala Badan Pertanahan Nasional Nomor 9 Tahun 1999 tentang Tata Cara Pemberian dan Pembatalan Hak Atas Tanah Negara dan Hak Pengelolaan.

Peraturan Menteri Dalam Negeri Nomor 19 Tahun 2016 tentang Pedoman Pengelolaan Barang Milik Daerah.

\section{Buku:}

Abdurrahman. (1996). Masalah-masalah Pencabutan Hak Atas Tanah dan Pengadaan Tanah Bagi Pelaksanaan Pembangunan Untuk Kepentingan Umum. Bandung: Citra Aditya Bakti. 
Boedi Harsono. (1971). Undang-Undang Pokok Agraria Isi dan Pelaksanaannya. Jakarta: Djambatan.

Irene Eka Sihombing. (2017). Segi-segi Hukum Tanah Nasional Dalam Pengadaan Tanah Untuk Pembangunan, Jakarta: Penerbit Universitas Trisakti.

Urip Santoso. (2013). Hukum Pengadaan Tanah Untuk Kepentingan Umum. Surabaya: Airlangga University Press. . (2015). Perolehan Hak Atas Tanah. Jakarta: Kencana Prenada Media. (2017). Hak Atas Tanah, Hak Pengelolaan, dan Hak Milik Atas Satuan Rumah Susun. Jakarta: Kencana Prenada Media. . (2019). Pendaftaran dan Peralihan Hak Atas Tanah. Cet. VI. Jakarta: Kencana Prenada Media.

\section{Jurnal/Majalah:}

A.P. Parlindungan, (Maret - April 1991). "Beberapa Konsep Tentang Hak-hak Atas Tanah". Majalah CSIS. Tahun XX No. 2. Jakarta, h. 135.

Boedi Harsono. (April 1990). "Aspek Yuridis Penyediaan Tanah". Majalah Hukum dan Pembangunan. Nomor 2 Tahun XX. Fakultas Hukum Universitas Indonesia, h. 168.
Eman Ramelan. (2006). "Hak Pengelolaan Setelah Berlakunya Peraturan Menteri Negara Agraria/ Kepala Badan Pertanahan Nasional No. 9 Tahun 1999". Jurnal YURIDIKA. Vol. 15 No. 3. Surabaya: Fakultas Hukum Universitas Airlangga, h. 196.

Maria S.W. Sumardjono. (1993). "Aspek Teoritis Peralihan Hak Atas Tanah Menurut UUPA". Majalah Mimbar Hukum. No. 18/X/1993. Yogyakarta: Fakultas Hukum Universitas Gadjah Mada, h. 11.

Urip Santoso. (Oktober 2010). "Perolehan Hak Atas Tanah Untuk Kepentingan Perusahaan Swasta". Jurnal Pro Justitia. Bandung: Fakultas Hukum Universitas Khatolik Parahiyangan, h. 213. . (2018). "Penggunaan Tanah Aset Pemerintah Kota Surabaya Oleh Pihak Ketiga Dalam Bentuk Izin Pemakaian Tanah (Perspektif Hukum Pertanahan)". Jurnal Perspektif. Volume 23 Nomor 3 Edisi September. Surabaya: Fakultas Hukum Universitas Wijaya Kusuma, h. 155.

\section{Makalah:}

Urip Santoso. (Mei 2019). "Ruislag Tanah Aset Pemerintah Daerah dan Tanah Perseroan Terbatas". Makalah. Surabaya: Fakultas Hukum Universitas Airlangga. 